\title{
Recycling cardboard wastes to produce blue oyster mushroom Pleurotus ostreatus in Iraq
}

\author{
Mustafa Nadhim Owaid ${ }^{1,2 *}$, Ahmed Mahali Abed ${ }^{3}$, Burhan Majed Nassar ${ }^{2}$ \\ ${ }^{1}$ Al-Athar School, Heet Education, Ministry of Education, Hit, Anbar 31007, Iraq; ${ }^{2}$ Department of Biology, College of Science, University of \\ Anbar, Ramadi, Anbar 31001, Iraq; ${ }^{3}$ Department of Biology, College of Education for Pure Sciences, Tikrit University, Tikrit 34001, Iraq
}

\section{A B S T R A C T}

\begin{abstract}
This study revealed successful use of industrial wastes to blue oyster mushroom cultivation as an easy method in Iraq. Some characteristics of yield were calculated using four substrates; S1 (100\% wheat straw), S2 (100\% cardboard), S3 (50\% wheat straw and $50 \%$ cardboard) and S4 (30\% wheat straw and 70\% cardboard), using two capacities of bags $30 \times 50 \mathrm{~cm}$ and $25 \times 20 \mathrm{~cm}$. The best total yield performance was $136.3 \mathrm{~g} / \mathrm{bag}$ by $\mathrm{S} 2$ in big bags; also, the best significant $(\mathrm{P}<0.05)$ biological efficiency $(\mathrm{BE})$ reached to $68.1 \%$ by same substrate in small bags, followed $49.5 \%$ and $35.6 \%$ for S3 and S4 by same type of bags. Anyway, the yield rate increased, the biological efficiency also increased, that due to a positive correlation $(r=0.41)$ between yield and biological efficiency. While, a negative correlation $(r=-0.36)$ between rates of fruiting bodies weight and their numbers appear in this study that agree many studies. In conclusion, the use of cardboard not only increased the yield but also provided more biological efficiency because of the positive correlations between biological efficiency on the one hand and the diameter of cap and productivity from another hand. The total yield by S2 was exceeding $466 \%$ comparison as $\mathrm{S} 1$ in big bags. The big bags were raised the productivity to average $170 \%$ compared with small bags too in general, which considered useful economically to raise the national income in large containers into cardboard as a cellulosic wastes instead of the common substrate (wheat straw), which used as a fodder for livestock in this homeland at least appreciation.
\end{abstract}

Keywords: Cardboard; Cultivation; Paper wastes; Pleurotus ostreatus; Yield

\section{INTRODUCTION}

Oyster mushroom Pleurotus ostreatus belongs to kingdom of fungi, phylum Basidiomycota (Stamets and Chilton, 1983). Mushrooms as fungi are heterotrophs that must obtain nutrients from organic sources. Because of secreted mushroom enzymes, it decomposes dead organisms to absorb as nutrients (Enger et al., 2012). However, Pleurotus spp. is found in Iraq wildly (Owaid et al., 2014b). As industrial wastes and agricultural residues in same time, cardboard is rich in cellulosic and lignocellulosic matters that can be utilized as a substrate at alone or in mixture with wheat straw, to cultivate and produce many edible mushrooms (Kulshreshtha et al., 2013).

At the first time, cultivation of $P$. ostreatus succeeded in 1900, and increased the importance of the its cultivation in easy methods (Chang and Miles, 2004), high nutritional and medicinal value, unique flavor (Ayodele et al., 2011) and antimicrobial activity (Alheeti et al., 2013a; Owaid et al., 2015a); also it has an active role on purifying polluted soil from heavy metals and crude oil (Emuh, 2010; Oyetayo et al., 2012). P. ostreatus is one of the most commercially important and successfully cultivated and considered as a delicacy after Agaricus bisporus and Lentinus edodes. Like Pleurotus ostreatus, many of Pleurotus mushrooms are primary decomposers of hardwood trees found worldwide. Approximately, seventy species of Pleurotus were recorded and new species were discovered (Kong, 2004). Royse (2002) was cultivated oyster mushroom in polyethylene bags that capacity $9.1 \mathrm{~kg}$ and $13.6 \mathrm{~kg}$. Generally, Pleurotus ostreatus was cultivated in bags, boxes (Kong, 2004) and bottles (Bao et al., 2004) in different sizes.

In Iraq, the first research about Pleurotus spp. cultivation was done by Hassan (1996) on various agricultural wastes available locally. Globally, Similar observations have been made by several researchers on oyster mushrooms using different agro-wastes such rice straw, paper, coffee pulp, sawdust, cotton waste, cotton seed hulls, corn cobs waste,

\footnotetext{
${ }^{*}$ Corresponding author:

Mustafa Nadhim Owaid, Al-Athar School, Heet Education, Ministry of Education, Hit, Anbar 31007, Iraq. E-mail: mustafa@alheeti.com, mustafanowaid@gmail.com
} 
bean straw, crushed bagasse, molasses wastes (Pandey, 2008), soybean straw, paddy straw, wheat straw (Ahmed et al., 2009), blotting paper (Epogee, 2011), handmade paper, cardboard (Kulshreshtha et al., 2010; Kulshreshtha et al., 2011; Kulshreshtha et al., 2013), cardboard with cane (Al-issawy, 2011), cardboard with plants paper and white sawdust (Mandeel et al., 2005), date palm residues (Hassan, 2011; Owaid, 2013; Alheeti et al., 2013b), waste paper with wood chips (Sofi et al., 2014) and Malaysian sawdust with rice bran (Owaid et al., 2015b).

Cardboard is a thick sheet of paper mainly used for packaging purposes. Cardboard is the last stage of paper making technology and it is produced when pulp fibres becomes too short to be recycled and used for making paper. Cardboards are rich in lignocellulosic residues (Kulshreshtha et al., 2013). What is produced from solid wastes in Iraq alone is estimated at 5446000 tons/year, around is $12.3 \%$ is burned according to statistics of year 2005 (UNSD, 2011). Cultivation of oyster mushrooms is a biotechnological process for ligno-cellulosic wastes recycling; can be produced at the level of the family in the home, garage, warehouse and old houses which provides an opportunity for the national income of the country (Yabraq et al., 2009). It might be the only current process that combines the production of protein-rich food with the reduction of environmental pollution (Sanchez, 2010). Therefore, many studies showed ability of growing oyster mushroom on semi-industrial media (In vivo) that contain extracts of some plant residues or wastes to know efficiency of use these as a substrate for cultivation many species of this mushroom (Stanley and Nyenke, 2011; Owaid et al., 2014a).

These industrial wastes are accumulated in the general place or street and produce vigorous odor. This work deals with the study of efficiency of residues, which located in Hit, Iraq. The aims of this research are defined as $-1^{\text {st }}$, to use paper (cardboard) wastes alone and in combination with the wheat straw to prepare newly suitable substrates for cultivation blue oyster mushroom Pleurotus ostreatus, besides that, testing yield, biological efficiency, number of flushes, weight of fruiting bodies and its numbers. $2^{\text {nd }}$, to analysis some quality properties that relating to size of fruiting bodies in various bags. $3^{\text {rd }}$, rid the environment from industrial cardboard and reduce levels of pollution by industrial wastes.

\section{MARERIALS AND METHODS}

\section{Production of spawn}

Mycelium of Pleurotus ostreatus (blue) was obtained from Plant and Pathological Fungi Lab. Department of Biology in College of Science/University of Anbar, Iraq. 450 grams of oyster mushroom's spawn was prepared using seeds of millet Pennisetum americanum in polypropylene bags that capacity $10 \times 30 \mathrm{~cm}$ after sterilized the wet seeds in bags using autoclave at $121^{\circ} \mathrm{C}$ and 1.5 psi for $30 \mathrm{~min}$, cooled, inoculated using $2 \times 2 \mathrm{~cm}$ mycelium piece, incubated at $25^{\circ} \mathrm{C}$ for fifteen days and saved at $4^{\circ} \mathrm{C}$ until use.

\section{Substrates preparation and pasteurization}

Cardboard pieces $5 \times 5 \mathrm{~cm}$ and wheat straw were obtained from Hit, Iraq and used as local substrates in four combinations, $100 \%$ wheat straw (S1), 100\% cardboard (S2), 50\% wheat straw and 50\% cardboard (S3), 30\% wheat straw and $70 \%$ cardboard (S4), in big and small polyethylene bags as shown in Table 1 . Substrates were saturate in water for $24 \mathrm{~h}$, pasteurized for $2 \mathrm{~h}$, drained from exceed water, added 5\% CaSO4 (based on dry weight), mixed as their combination (Table 1) and cooled for ready to inoculated. Three percentage of spawn was used for inoculation the substrates based on wet weight (Singh and Singh, 2011).

\section{Cultivation and yield performance}

Mixtures of substrates were used for cultivation blue oyster mushroom using layer in depth $5 \mathrm{~cm}$, spawn was added, other layer of substrate added accordingly until filling then closed. Incubation was achieved at $24 \pm 1^{\circ} \mathrm{C}$ darkly

Table 1: Ingredients of agri-mixtures and properties of cultivation containers

\begin{tabular}{lcccc}
\hline Bags size & \multicolumn{4}{c}{ Substrate combinations } \\
\cline { 2 - 5 } & S1 & S2 & S3 & S4 \\
\hline Bag 30×50 cm (wet weight) & 1500 & 1500 & 1500 & 1500 \\
Bag 30×50 cm (dry weight) & 320.25 & 568.5 & 444.45 & 494.1 \\
Bag 20×25 cm (wet weight) & 500 & 500 & 500 & 500 \\
Bag 20×25 cm (dry weight) & 106.75 & 189.5 & 148.15 & 164.7 \\
Relative humidity (\%) & 78.65 & 62.1 & 70.37 & 67.06
\end{tabular}

S1: $100 \%$ wheat straw, S2: $100 \%$ cardboard, S3: $50 \%$ wheat straw and $50 \%$ cardboard, S4: $30 \%$ wheat straw and 70\% cardboard. Unit of weight (gram).

The dry weight was used to caculate the bioilogical effeciency

Table 2: Quantity characteristics of blue oyster mushroom

\begin{tabular}{|c|c|c|c|c|c|}
\hline \multirow[t]{2}{*}{ Features } & \multirow[t]{2}{*}{ Bags } & \multicolumn{4}{|c|}{ Substrate combinations } \\
\hline & & S1 & S2 & S3 & S4 \\
\hline Yield g/bag & B1 & 30.5 & 136.3 & 103.7 & 102.0 \\
\hline LSD $(P<0.05) 5.01$ & B2 & 17.3 & 72.7 & 73.3 & 58.7 \\
\hline Biological efficiency \% & B1 & 5.4 & 42.6 & 23.3 & 20.6 \\
\hline $\operatorname{LSD}(P<0.05) 1.29$ & B2 & 9.1 & 68.1 & 49.5 & 35.6 \\
\hline No. of flushes & B1 & 1 & 2 & 2 & 1 \\
\hline LSD $(P<0.05) 0.00$ & B2 & 1 & 2 & 3 & 2 \\
\hline Fruiting body weight $\mathrm{g}$ & B1 & 10.2 & 13.2 & 11.6 & 13.4 \\
\hline LSD $(P<0.05) 2.83$ & B2 & 13.0 & 10.9 & 24.4 & 18.0 \\
\hline No. of Fruiting bodies & B1 & 3.0 & 10.3 & 9.0 & 7.7 \\
\hline LSD $(P<0.05) 0.93$ & B2 & 1.3 & 6.7 & 3.0 & 3.3 \\
\hline
\end{tabular}

B1: Big bags that capacity $1.5 \mathrm{~kg}$ based on wet matter, B2: Small bags that capacity $0.5 \mathrm{~kg}$ based on wet matter. S1: $100 \%$ wheat straw, S2: 100\% cardboard, S3: 50\% wheat straw and 50\% cardboard, S4: $30 \%$ wheat straw and $70 \%$ cardboard 
for three weeks up to completion growth of mycelia in whole bag. Ten Celsius for $48 \mathrm{~h}$ was done as cold shock to induce primordial formation, packets opened with $24 \pm 1^{\circ} \mathrm{C}, 80-90 \%$ humidity, lighted using fluorescent light and aerated twice per day so form primordia, which developed to fruiting bodes that harvested in best size (Epogee, 2011).

The determined yield after thirty days was subsequently used to calculate biological efficiency using this formula: $\mathrm{BE} \%=($ fresh yield $\mathrm{g} / \mathrm{dry}$ weight of substrate in spawning phase g) $\times 100$. Also, average weight of fruiting bodies, number of fruiting bodies, number of flushes, the diameter of pileus (cap) and the diameter and length of stipe (Beyer and Muthersbaugh, 1996).

\section{Statistical analysis}

The experimental data were subjected to an analysis of variance by two ways analysis (ANOVA) using GenStat Discovery Edition computer program version 7 DE3 (VSN International Ltd., UK) to determine the least significant difference among means at the level least of $0.05(\mathrm{P}<0.05)$. Three replicates were examined in the experiments.

\section{RESULTS AND DISSCUSION}

In this research, after thirty days, the total yield (Fig. 1) was completed by using four substrates as seen in Table 2 by using two different sizes of polyethylene bags that capacity $1.5 \mathrm{~kg}$ (big) and $0.5 \mathrm{~kg}$ (small) based on wet matter. The best significant $(\mathrm{P}<0.05)$ yield of blue oyster mushroom Pleurotus ostreatus was $136.3 \mathrm{~g} / \mathrm{bag}$ achieved on $100 \%$ cardboard substrate (S2) in big bags, followed 103.7 and $102 \mathrm{~g} / \mathrm{bag}$ using S3 (50\% wheat straw plus 50\% cardboard) and S4 (30\% wheat straw plus 70\% cardboard) substrates in big bags successively. However, lesser harvested yield was 17.3 and $30.5 \mathrm{~g} / \mathrm{bag}$ by wheat straw alone (S1) as a control in small and big bags respectively. Generically, on the basis of above, data it could be concluded that the total yield using cardboard alone (S2) was exceeding $446 \%$ and $420 \%$ in big bags and small one respectively compared with

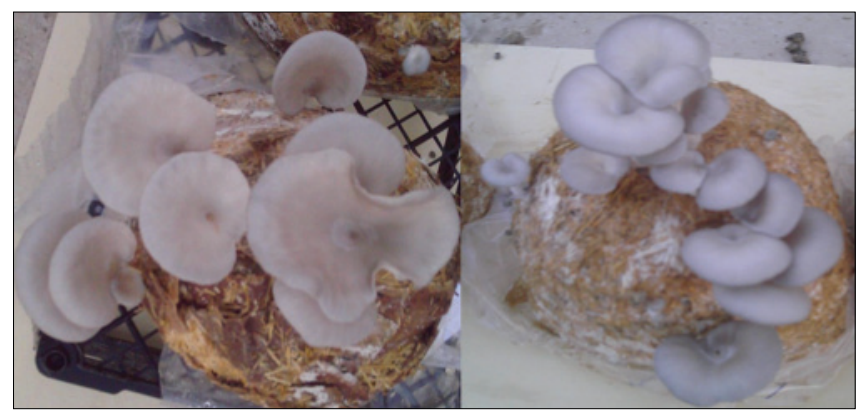

Fig 1. Fruiting bodies of $P$. ostreatus in big bags of mixture of cardboard $\&$ wheat straw (left) and wheat straw alone as control (right) wheat straw substrate (S1). Likewise, big bags were raised the productivity to average $170 \%$ compared with the small bags for four mixtures in general.

In other quantity characteristic (Table 2), biological efficiency (BE) reached to $68.1 \%$ for S2 in small bag, significantly $(\mathrm{P}<0.05)$; followed $49.5 \%$ and $35.6 \%$ with S3 and S4 in small bags, respectively. Whereas, lesser biological efficiency was observed on wheat straw alone that reached to $5.4 \%$ and $9.1 \%$ using large and small bags, respectively. The concluded was that big bags best than small ones in yield and biological efficiency because the more substrates allow to more growing than smaller container (Royse, 2002). The yield and biological efficiency are linked together in a positive correlation $(r=0.41)$, as the yield rate increased, the biological efficiency also increased. Table 4 showed a positive correlation $(r=0.71)$ between biological efficiency and flushes number. Also, Table 4 showed a positive correlation among yield and biological efficiency on side and number of flushes and size of caps on another side.

In this experiment, number of flushes was increased in small bags compared within big ones. The best significant $(\mathrm{P}<0.05)$ flushes number was 3 flushes on $\mathrm{S} 3$ in small bags, followed two flushes on S2 and S4 in same bags, whereas only one flush was achieved on S1 (control). The bigger mean of fruiting bodies weight was $24.4 \mathrm{~g}$ on S3 significantly $(\mathrm{P}<0.05)$, followed $18 \mathrm{~g}$ on $\mathrm{S} 4$ in small bags. While $\mathrm{S} 1$ in big bags was given lesser rate of the fruiting bodies weight than others reached to $12.1 \mathrm{~g}$.

The number of fruiting bodies was successfully raised when the cardboard found in ingredients of mixture. In significant $(\mathrm{P}<0.05)$, the big bags had 10,9 and 8 fruiting bodies on S2, S3 and S4 successively, whilst small bags given nearly 4 fruiting bodies. Anyway, a negative correlation $(r=-0.36)$ between rates of fruiting bodies weight and their numbers (Table 4), that agrees with Owaid (2013) who referred to same result; when increased the number of oyster mushrooms' fruits lead to decrease their weights.

Table 3: Quality characteristics of blue oyster mushroom

\begin{tabular}{llllll}
\hline Features & Bags & \multicolumn{4}{c}{ Substrate combinations } \\
\cline { 3 - 6 } & & $\mathbf{S 1}$ & S2 & S3 & S4 \\
\hline Diameter of cap $(\mathrm{mm})$ & B1 & 6.2 & 7.1 & 7.0 & 5.8 \\
LSD $(\mathrm{P}<0.05)$ 0.99 & B2 & 5.3 & 6.8 & 5.9 & 6.9 \\
Diameter of stipe $(\mathrm{mm})$ & B1 & 1.0 & 1.4 & 1.2 & 1.1 \\
LSD $(P<0.05) 0.33$ & B2 & 1.1 & 1.2 & 1.2 & 1.2 \\
Length of stipe $(\mathrm{mm})$ & B1 & 2.5 & 3.2 & 3.5 & 2.7 \\
LSD $(P<0.05) 0.48$ & B2 & 3.6 & 2.7 & 2.8 & 2.7
\end{tabular}

B1: Big bags that capacity $1.5 \mathrm{~kg}$ based on wet matter, B2: Small bags that capacity $0.5 \mathrm{~kg}$ based on wet matter. S1: $100 \%$ wheat straw, S2: $100 \%$ cardboard, S3: $50 \%$ wheat straw and $50 \%$ cardboard, S4: $30 \%$ wheat straw and $70 \%$ cardboard 
Table 4: Correlation among characters

\begin{tabular}{|c|c|c|c|c|c|c|c|c|}
\hline Correlation & $\begin{array}{l}\text { Total } \\
\text { yield }\end{array}$ & $\begin{array}{l}\text { No. of fruiting } \\
\text { bodies }\end{array}$ & $\begin{array}{c}\text { Fruiting } \\
\text { body weight }\end{array}$ & $\begin{array}{l}\text { Number } \\
\text { of flushes }\end{array}$ & $\begin{array}{l}\text { Biological } \\
\text { efficiency }\end{array}$ & $\begin{array}{c}\text { Diameter } \\
\text { of cap }\end{array}$ & $\begin{array}{c}\text { Diameter } \\
\text { of stipe }\end{array}$ & $\begin{array}{l}\text { Length } \\
\text { of stipe }\end{array}$ \\
\hline Total yield & 1.000 & & & & & & & \\
\hline No. of fruiting bodies & 0.913 & 1.000 & & & & & & \\
\hline Fruiting body weight & 0.030 & -0.360 & 1.000 & & & & & \\
\hline Number of flushes & 0.216 & 0.018 & 0.596 & 1.000 & & & & \\
\hline Biological efficiency & 0.411 & 0.299 & 0.318 & 0.714 & 1.000 & & & \\
\hline Diameter of cap & 0.465 & 0.483 & -0.093 & 0.243 & 0.373 & 1.000 & & \\
\hline Diameter of stipe & 0.422 & 0.358 & 0.121 & 0.201 & 0.385 & 0.356 & 1.000 & \\
\hline Length of stipe & 0.078 & 0.157 & -0.192 & -0.191 & -0.207 & -0.171 & 0.082 & 1.000 \\
\hline
\end{tabular}

The biological efficiency depends on the yield size (Beyer and Muthersbaugh, 1996), viz. positive correlation between productivity and biological efficiency (Table 4), which affected by dry weight of substrate that lead to increased biological efficiency in small packets (Table 2). Also, the productivity and biological efficiency were increased in some mixtures as comparison with wheat straw alone because of variation of capability these substrates to save and aid the nutritional and environmental requirements and difference of their containing from cellulose, hemicellulose and lignin (Kuhad et al., 1997).

Small size of gradients of the substrate wheat straw has large influence on oyster mushroom growth, compared with pieces of cardboard (big), which lead to increasing decomposed the wheat straw and big biomass of mycelia formed because of increasing the substrate surface area for mycelia growth, thus clusters were grew up on this substrate (Aswad, 2005).

On the other side, the quality properties of produced mushroom (Table 3) such as rates of diameter of caps and stipe and length of stipe were calculated. Maximum diameter of cap was obtained significantly $(\mathrm{P}<0.05)$ on $\mathrm{S} 2$ in big bags, $7.1 \mathrm{~mm}$, followed $7 \mathrm{~mm}$ by S3 in same bag size. The minimum diameter was $5.3 \mathrm{~mm}$ achieved on $\mathrm{S} 1$ in small bags. The rate of diameter of stipe reached nearly $1.4 \mathrm{~mm}$ on S2 compared as approx. $1 \mathrm{~mm}$ on S1 as control. Generally, length of stipe reached to $3 \mathrm{~mm}$ in this experiment approximately.

The decline of determinations of caps in small bags with all substrates may be return to close fruiting bodies from others because of small area with these packets, which lead to small size of fruiting body in small bags. Whereas in the big containers; fruiting bodies have best chance to grow and extend; that due to big size of container that gave big size of fruiting body. The increasing means of weight of fruiting bodies (Table 2) and diameter of caps (Table 3) belong to available environment to grow big biomass with some substrates that hasten the fruiting bodies formation (Aswad 2005). Good explication of results in Tables 2 and 3 was given according to positive correlations (Table 4) between number of flushes and biological efficiency on the one hand and the diameter of cap and total yield from another hand.

\section{CONCLUSION}

This paper showed the successful using of cardboard, wheat straw and their combinations to cultivate Pleurotus ostreatus using two sizes of bags $30 \times 50 \mathrm{~cm}$ and $25 \times 20 \mathrm{~cm}$. The best total yield was $136.3 \mathrm{~g} / \mathrm{bag}$ using cardboard substrate in big bags, while the significant $(\mathrm{P}<0.05)$ biological efficiency (BE) reached to $68.1 \%$ using same media in small bags. In conclusion, using of cardboard not only increased the yield and fruits size but also provided more biological efficiency. That has positive correlations between biological efficiency on the one hand and the diameter of cap and productivity from another hand. In general, the total yield on cardboard was exceeding $446 \%$ and $420 \%$ in big bags and small one respectively comparison as wheat straw substrate (S1). Likewise, big bags were raised the productivity to average $170 \%$ compared with small bags, which considered useful economically to raise the national income by using cardboard as a cellulosic wastes instead of the common substrate, wheat straw, which used as a fodder for livestock in this country (Iraq) at least appreciation.

\section{Author contributions}

All authors contributed in achievement this work in each part. Spawn preparation done by M. N. O.; A. M. A. collected the cellulosic wastes from shops and agricultural fields. The experiment was completed in Hit city, Iraq, and B. M. N. did the follow-up, harvested the crop and collected data with A. M. A. The Statistical Analysis was made by M. N. O. who discussed these results with all co-authors and edited it.

\section{REFERENCES}

Ahmed, S. A., J. A. Kadam, V. P. Mane, S. S. Patil and M. M. V. Baig. 2009. Biological efficiency and nutritional contents of Pleurotus florida (Mont.) Singer cultivated on different agro-wastes. Nat. Sci. 7: 44-48. 
Alheeti, M. N. O., S. S. S. Al-Saeedi, I. A. Al-Assaffii and V. Sabaratnam. 2013a. Antifungal activities of mycelia and culture filtrate of four oyster mushroom species (Pleurotus spp.) against pathogenic Fungi. The $7^{\text {th }}$ International Medicinal Mushroom Conference, Beijing, China.

Alheeti, M. N. O., S. S. S. Al-Saeedi and I. A. Al-Assaffii. 2013b. Evaluation of qualification of substrates containing date palm fibers (leef) and sawdust on quality and productivity of four Pleurotus spp. $2^{\text {nd }}$ Conference of Desert Studies, Ramadi, Iraq.

Al-Issawy, K. J. F. 2011. Improve the local components of the substrate to increase the production oyster mushroom Pleurotus ostreatus. M.Sc. Thesis, College of Agriculture, University of Anbar, Iraq.

Aswad, H. B. 2005. Effect of microbial biotechnological and media mixtures on production of oyster mushroom (Pleurotus ostreatus). M.Sc. Thesis, College of Agriculture, University of Anbar, Iraq.

Ayodele, S. M., E. O. Akpaja and Y. Adamu. 2011. Some edible and medicinal mushrooms of Igala land in Nigeria, thier socioucultural and ethnomycological uses. I. J. S. N. 2: 473-476.

Bao, D., S. Kinugasa and Y. Kitamoto. 2004. The biological species of oyster mushrooms (Pleurotus spp.) from Asia based on mating compatibility tests. J. Wood Sci. 50: 162-168.

Beyer, D. M. and H. R. Muthersbaugh. 1996. Nutritional factors affecting later break yield of Agaricus bisporus. Can. J. Plant Sci. 76: 835-840.

Chang, S. T. and P. G. Miles. 2004. Mushrooms Cultivation, Nutritional Value, Medicinal Effect and Enviromental Impact. $2^{\text {nd }}$ ed. CRC Press LLC, USA. p. 451.

Emuh, F. N. 2010. Mushroom as a purifier of crude oil polluted soil. I. J. S. N. 1: 127-132.

Enger, E. D., F. C. Ross and D. B. Bailey. 2012. Concepts in Biology. $14^{\text {th }}$ ed. McGraw-Hill, p. 473.

Epogee Ltd. 2011. How to Grow Oyster Mushroom. Sheet. Mushroom Box Company. Epogee Ltd., London. p5.

Hassan, A. A. 1996. Production of Pleurotus spp. for human consumption on agricultural wastes and utilization its byproducts for animal feed. M.Sc. Thesis, University of Baghdad. Iraq.

Hassan, I. A. 2011. Effect of sterilization on the yield and storage life of oyster mushroom cultivated on date palm by products. M.Sc. Thesis, College of Agriculture, University of Baghdad, Iraq.

Kong, W. S. 2004. Spawn. In: Oyster Mushroom Cultivation. Vol. 1. Mush World, Aloha Medicinals Inc., Korea. pp. 54-61.

Kuhad, R. C., A. Singh and K. E. L. Eriksoon. 1997. Microorgansims and enzymes involved in the degradation of plant fiber cell walls. In: Eriksson, K. E. L., editor. Advances in Biochemical Engineering Biotechnology. Springer-Verlag, Germany. pp. 46-125.

Kulshreshtha, S., N. Mathur and P. Bhatnagar. 2011. Pros and cons of $P$. florida cultivation for managing waste of handmade paper and cardboard industries. The IIOAB J. 2: 45-48.

Kulshreshtha, S., N. Mathur, P. Bhatnagar and B. L. Jain. 2010. Bioremediation of industrial waste through mushroom cultivation. J. Environ. Biol. 31: 441-444.

Kulshreshtha, S., N. Mathur, P. Bhatnagar and S. Kulshreshtha. 2013.
Cultivation of Pleurotus citrinopileatus on handmade paper and cardboard industrial wastes. Ind. Crops Prod. 41: 340-346.

Mandeel, Q. A., A. A. Al-Laith and S. A. Mohamed. 2005. Cultivation of oyster mushrooms (Pleurotus spp.) on various lignocellulosic wastes. World J. Microbiol. Biotech. 21: 601-607.

Owaid, M. N. 2013. Testing efficiency of different agriculture media in growth and production of four species of oyster mushroom Pleurotus and evaluation the bioactivity of tested species. Ph.D. dissertation, College of Science, University of Anbar, Iraq.

Owaid, M. N., M. M. Muslat and W. C. Tan. 2014b. First collection and identification of wild mushrooms in western Iraq. J. Adv. Lab. Res. Biol. 5: 29-34.

Owaid, M. N., S. S. S. Al-Saeedi and I. A. Al-Assaffii. 2014a. Impact palm date fibers (fibrillum) and sawdust extract on mycelial growth rate of four species of Pleurotus. J. Tikrit Univ. Agric. Sci., $3^{\text {rd }}$ Sci Conf Plant Prod 14: 1-7.

Owaid, M. N., S. S. S. Al-Saeedi, and I. A. Al-Assaffii. 2015a. Antimicrobial activity of mycelia of oyster mushroom species (Pleurotus spp.) and their liquid filtrates (in vitro). J. Med. Bioeng. 4: 376-380.

Owaid, M. N., S. S. S. Al-Saeedi, V. Sabaratnam, I. A. A. Al-Assaffii and J. Raman. 2015b. Growth performance and cultivation of four oyster mushroom species on sawdust and rice bran substrates. J. Adv. Biotech. 4: 424-429.

Oyetayo, V. O., A. O. Adebayo and A. Ibileye. 2012. Assessment of the biosorption potential of heavy metals by Pleurotus tuberregium. I.J.A.B.R. 2: 293-297.

Royse, D. J. 2002. Influence of spawn rate and commercial delayed release nutrient levels on Pleurotus cornucopiae (oyster mushroom) yield, size, and time to production. App. Microbiol. Biotech. 58: 527-531.

Sanchez, C. 2010. Cultivation of Pleurotus ostreatus and other edible mushrooms. App. Microbiol. Biotech. 85: 1321-1337.

Singh, M. P. and V. K. Singh. 2011. Yield performance and nutritional analysis of Pleurotus citrinopileatus on different agrowastes and vegetable wastes. Proceedings of the $7^{\text {th }}$ International Conference on Mushroom Biology and Mushroom Products. Section: Waste conversion, substrates and casing. pp355-392.

Sofi, B., M. Ahmad and M. Khan. 2014. Effect of different grains and alternate substrates on oyster mushroom (Pleurotus ostreatus) production. Afr. J. Microbiol. Res. 8: 1474-1479.

Stamets, P. and J. S. Chilton. 1983. Mushroom Cultivator: A Practical Guide to Growing Mushrooms at Home. Agarikon Press, Washington, p. 415.

Stanley, H. O. and C. U. Nyenke. 2011. Cultural studies on mycelia of Pleurotus pulmonarius (oyster mushroom) in selected culture media. I. J. S. N. 2: 183-185.

Thomas, M. G. and D. R. Schumann. 1993. Income Opportunities in Special Forest Products-Self-Help Suggestions for Rural Entrepreneurs. Agriculture Information Bulletin AIB, U.S. Department of Agriculture, Washington. pp139-149.

UNSD. 2011. Environmental Indicators Waste, Municipal Waste Treatment. Excel Data Sheet. United Nation.

Yabraq, M. M., I. Elias and H. Mando. 2009. Cultivation of oyster mushroom Pleurotus spp. General Commission for Scientific Agricultural Research (GCSAR), Aleppo, Syria. pp22. 